\title{
Plant Molluscicides
}

\author{
H. Kloos ${ }^{\star}$ and F. S. McCullough ${ }^{\star \star}$ \\ * Department of Epidemiology and International Health, University of California, San Francisco, U.S.A. \\ ** Ecology and Control of Vectors, Division of Vector Biology and Control, World Health Organization, Geneva, Switzerland
}

Received: February 5, 1982

Accepted: May 10, 1982

\section{Key Word Index:}

Molluscicidal Plants; Molluscicide; Snail Control; Schistosomiasis; Screening Methods; Target Organisms; Toxicity Levels.

\section{Introduction}

National and international institutions are both currently giving increasing attention to the study of plant molluscicides in the hope that they may prove cheaper and more readily available than synthetic chemicals. Many developing countries are reluctant to embark on chemical snail control progranmes, using costly synthetic compounds bought from industrialized nations with scarce hard currency [28, 88]. Recent rigorous legislation governing pesticide development und use, has tended to discourage the chemical industry from carrying out research even on promising synthetic compounds [137]; not surprisingly, very few candidate molluscicides are presently available [80]. Whereas synthetic chemicals biodegrade slowly, and preliminary evidence suggests that some populations of snail hosts may have developed resistance to them $[7,80]$, plant extracts are quite rapidly reduced to simpler substances $[57,88,89]$. Some recent studies of plant molluscicides give preliminary indications that they may be applied effectively in different habitats using techniques available in, and appropriate to, developing countries. Moreover, the use of indigenous, rather than imported, materials is desirable, especially as strategies for schistosomiasis control programmes should be based on long-term operations. Such strategies should ideally employ a multiplicity of methods (including population chemotherapy, focal and seasonal snail host control, environmental and sanitation improvement and health education), rather than a single approach.

Research on plant molluscicides has become multidisciplinary and, as a consequence, the findings have been reported in a wide variety of journals. No com- prehensive review on plant molluscicides having yet been published, the purpose of this paper is to assemble pertinent information and provide general guidelines and recommendations relevant to further research on plant molluscicides and their role in control programmes.

\section{Review}

Interest in plant molluscicides dates from the 1930's when ARCHIBALD [12] and WAGNer [131] advocated planting the desert palm, Balanites aegyptiaca and $B$. maughamii, along the water courses of the $\mathrm{Su}-$ dan and southern Africa, respectively. The laboratory and field trials of these scientists indicated that the fruit which fell into the water inhibited the increase of snail population density. These encouraging findings prompted the introduction of B. aegyptiaca to Puerto Rico, where it was planted around a Biomphalaria glabrata infested pool with apparently beneficial results [99]. Mozı.Ey [86, 87] considered this and two other saponin-containing plants, Sapindus saponaria, the berries of which were widely used in Africa and South America as a fish poison and soap, and Swartzia madagascariensis, a traditional African medicine and fish poison [131], to be among the most promising of vegetable molluscicides. Using the berries of $S$. saponaria, he controlled a population of Bulinus (Physopsis) africana in a pond in Zanzibar. In South America, preliminary studies by LutTERMOSER [73] in Venezuela, and by Pinto and Almeida [98] in Brazil, showed that the berries of $S$. saponaria were lethal to numerous microscopic organisms, as well as to the host snails of Schistosoma and Fasciola [129]. Synergistic effects were found between extracts of $S$. saponaria and sodium pentachlorophenate $[17,85]$. None of these plants, nor several additional Old World fish poisons $[87,110,126]$, was further exploited for the control of snails. Not until the mid-1960's was the first plant (Phytolacca dodecandra) used for control of schistosomiasis in an endemic focus, in Ethiopia [62]. 
Stimulated by these early studies, the search for plants with molluscicidal potential was intensified as exemplified by extensive screening and general improvement of methods and techniques (Table II). Amorin and Pessoa [10] randomly screened fresh material of nine plants indigenous to Alagoas State, Brazil. Three of the plants, Paullinia pinnata, Stenolobium velutinum and Piptadenia macrocarpa, were found to be only mildly molluscicidal at $1000 \mathrm{ppm}$, apparently due to the green state of the plants. SiLva et al. [117] screened another 30 species indigenous to Brazil, of which four were toxic to Biomphalaria straminea, but only one, Agonandra brasiliensis, was molluscicidal at $100 \mathrm{ppm}$. Possible confinement of the active ingredient in the bark, which regenerates slowly, of $A$. brasiliensis and Brysonima sericea (other parts of the plants were not tested) probably precludes their practical use for snail control. The bark of Ziziphus undulata was found to have no effect on the snails, but Barbosa and Mello [18] reported 30 percent mortality in Biomphalaria glabrata exposed to a $10 \mathrm{ppm}$ water extract of $Z$. joazeiro. In northeast Brazil several of about one hundred plants studies, including Pithecellobium multiflorum and Piper tuberculatum, showed promising molluscicidal activity [105]. However, fish succumbed at concentrations lower than those which killed snails [106], and the resistance of the plants to physiochemical stress (sunlight, temperature, silt and $\mathrm{pH}$ ) remains to be studied before their suitability can be more fully assessed.

Medina and Woodbury [82] tested 198 plants indigenous to Puerto Rico and two to the Dominican Republic. The plants selected for screening were from genera known to have molluscicidal activity, plants with medicinal or toxic effects in man or domestic animals, as well as some species randomly selected from areas infested with lymnaeid snails. All parts of the plant were tested. Thirty species were found to be lethal to Lymnaea cubensis and $L$. columnella in water extract of $1000 \mathrm{ppm}$. For further screening these plant products were oven-dried and tested in water extracts at 25, 100, 200 and $1000 \mathrm{ppm}$. Although $\mathrm{He}$ dychium coronarium yielded the most potent extract, Solanum nodiflorum was selected for further study, due to the uniform distribution of the molluscicidal principle in all parts of the plant $[82,83]$. All other species exhibited great variations in potency, but the highest toxicity levels were most often found in the flowers and leaves. Several species of Solanum are being cultivated for solasodine, a sapogenin used in the production of pharmaceutical steroids, and attempts are being made to cultivate $S$. mammosum in Puerto Rico [128]. Solasodine and possible solamargine, another glycoalkaloid in the fruits of $S$. mammosum, were significantly more toxic than the crude aqueous and methanolic extracts [8]. Although the small number of species tested by MEdinaand WoodBURY [82] do not permit detailed comparisons betwe- en plant families, it was noted that the greatest proportion of molluscicidal plants found was in the Solanaceae ( 8 of 14 plants tested), Phytolaccaceae (both species), Fabaceae ( 3 of 15 ), Rubiaceae ( 2 of 12 ) and Euphorbiaceae (2 of 13). All 9 species of the family Compositae and the 6 grasses were found to be nontoxic to snails. These findings reveal certain similarities and contrasts to other studies. Thus, although $\mathrm{Ja}$ tropha curcas had no effect on Lymnaea sp. in Puerto Rico [82], its roots proved highly molluscicidal against Oncomelania quadrasi in the Philippines [142], and its seeds moderately so against Bulinus truncatus in Sudan [32]. Whereas Randia aculeata and Canna sp. were well tolerated by Lymnaea sp., [82], the fruit

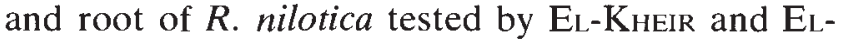
Tohami [32], and Canna indica tested by Mahran et al. [75], and Adewunmi and Sofowora [5], were molluscicidal. Paullinia pinnata, well tolerated by lymnaeid snails [82], caused 100 percent mortality in $B$. glabrata as a $1000 \mathrm{ppm}$ water extract [10], but species of Ipomoea, Urera and Serjania were nontoxic in both studies. Similarly, Borreria vercillata and the two species of Annona tested by Medina and WoodBURY [82] and SILVA et al. [117], showed no molluscicidal activity at $1000 \mathrm{ppm}$. The toxicity of two species of Phytolacca against Lymnaea spp. corroborates the findings of several investigators [56].

Twenty-three of the 181 methanolic extracts $(12.7$ percent), representing 106 plant species used in Nigerian herbal medicine, gave 100 percent kill against Bulinus (P.) globosus [5]. They include the root of Rauvolfia caffra, the stem and root of Bombax costatum, the fruit of Dialium guineense, the root and stem of Combretum spp., and the root of Terminalia mollis, the root of Cyrptogonone argentea, the stem of Acioa emenii and $A$. ruatisii, the leaves of Morinda lucida and Rothmania whitefieldii, and the leaves of Xiris anceps.

The suitability of plants having molluscicidal activity only in the roots and stems depends primarily on their rate of growth, potency and amount of labour involved in digging up the roots. Plants endowed with regenerative fruiting parts and seeds, being more easily harvested, transported and processed, should normally be given preference. Nevertheless, vegetatively grown tubers may be used advantageously in some locales, since they may not require milling or storage and can remain in the ground until used. Their weight and bulk, however, pose problems during digging and transportation, as noted by TEESDALE [126], who field-tested the root of Neorautanenia pseudopachyrhizus in Kenya.

The most extensive plant screening programme has been carried out in China, where nearly 600 indigenous herbs were tested for snail toxicity. Fewer than 20 were mildly toxic in concentrations of $10.000 \mathrm{ppm}$ and lower; no plant was considered to be cost-effective for large-scale use [74]. 
Some of the reported variations in toxicity between plants studied by different investigators are probably due to differences in collection methods, plant varieties and ecotypes, extraction solvents and snail species and subspecies used. Unfortunately, exact locations of plant collection sites and maturation stage are seldom indicated in reports, and duplicate specimens are not always secured for deposition in herbaria for reference purposes. Concentration of active substances varies not only among different plant parts, but also among specimens from the same species growing in the same areas [82]. Although many plant materials are more efficiently extracted when ripe and in powder form, higher potencies were reported for the green and semi-ripe, than for the fully ripe berries of Phytolacca dodecandra $[54,71]$; moreover, female plants of this dicot are more toxic than male plants [54]. Identification of plants is not always complete or correct, due to failure to obtain flowering and fruiting parts and to lack of competent plant taxonomists. Several investigators $[32,132]$, while searching for the most potent molluscicides, failed to report findings on plants possessing no molluscicidal attributes but which might be useful for comparative studies, or in reducing duplication of work in an attempt to lower research costs [36]. The discovery that the bark of dogwood (Cornus florida) is toxic to snails [45] is of little relevance for control of snailtransmitted diseases, since this plant occurs only in the higher latitudes of North America and Eurasia [100].

Another problem in developing molluscicidal plants is the lack of information on their toxicity to man, domestic animals and non-target aquatic fauna and flora, although the relatively few plant species screened for molluscicidal activity have already been studied chemically and pharmacologically $[14,44$, 130, 133]. Croton tiglium, studied in China and in the Philippines, has a potency against $O$. quadrasi comparable to that of the synthetic molluscicide Bayluscide ${ }^{\circledR}$, but is hazardous for snail control due to the carcinogenic effect of croton oil [24, 142]; it shows antileukemic activity at low dosages [25]. The seeds of the closely related $C$. macrostachys, known by the same vernacular name as $C$. tiglium in Sudan, and considered promising for snail control $[9,28]$, also need to be studied for possible carcinogenicity. Another plant indigenous to the Philippines, Entada phaseoloides, was lethal against $O$. quadrasi at low concentrations and was stable under various physiochemical stresses, but killed fish below its molluscicidal level. The relatively high doses required to obtain a satisfactory molluscicidal effect in a field trial, as well as the use of its bark, mitigate against its application in control programmes [140].

Other plants, whose toxicity should be studied before being subjected to intensive molluscicidal tests, include species of the genus Derris, some of which have been associated with human fatalities, and $J a$ tropha spp. [86, 124] and Securidaca longepedunculat $a$ which has been used as a homicidal plant and fish poison in Angola [15]. Research on Euphorbia candelabrum was discontinued in Ethiopia due to its toxicity in man, in spite of the fact that its latex was molluscicidal at $20 \mathrm{ppm}$. The seeds of the common castor plant, (Ricinus communis), were nonmolluscicidal $[22,82]$. The three furcoumarins in Ammi majus, including bergapten, claimed to be as active as sodium pentachlorophenate (NaPCP) in Egypt, and safe for handling [1], are all strong dermal photosensitizers [111].

The discovery of molluscicidal and snail-repellent hydrophytes, and of plant wastes that are toxic to snails, has further increased the prospects of developing plant molluscicides, using simple technology. Aquatic plants provide support, food and shelter for the survival and maintenance of snail intermediate hosts. BousfiELD [23] found strong associations between rheotaxis of $B$. glabrata snails and various plant species. While extracts from Potamogeton crispus and lettuce (Lactuca sativa), among other plants, attracted the snails, those of Apium nodiflorum and water cress (Rorippa nasturtium aquaticum) repelled them.

These differences were attributed to antagonistic substances in plants which may interfere with the chemical sensory mechanisms of snails and inhibit or reduce positive rheotaxis. This hypothesis is supported by the results of several other studies. MaHRan and coworkers [75] noticed a general absence both of snails and dead specimens in stretches of water courses inhabited by Canna indica, which is molluscicidal. In Kenya Dossaji et al. [30] noted high mortality of snails in a reservoir where Polygonum senegalense forma senegalense was abundant. An extract of fresh leaves was found to be slightly molluscicidal; the chemical structure of the active principle, phenolic glycoside, was studied by Maradufu and Ouma [78]. The freshwater alga Chara vulgaris was associated with high snail mortality in aquaria [103]. However, the algal complex Mycrosystis farlowiana/Pseudanabaena franqueti was molluscicidal against Lymnaea sp. only at high concentrations [42]. WARREN and PETERS [132] reported that Schistosoma mansoni cercariae penetrated the integument of the string bean (Phaseolus vulgaris) but not of 81 aquatic plants, one of which, Hedychium coronarium, released a cercariacide when cut, suggesting that this and other plants studied (none was listed in their report) may be molluscicidal as well. During another screening programme 20 of 100 essential oils, containing diterpenes, sesquiterpenes and related substances, inhibited penetration of $S$. mansoni cercariae through the skin of mice, seven of them killing all cercariae [36].

Some food and fibre plants, widely cultivated and processed in the tropics and subtropics, yield waste 
products which are toxic to snails. The waste from sisal (Agave sisalana), discarded by some factories into rivers in Tanzania, kept large stretches of water free from schistosome-transmitting snails, apparently as a result of oxygen depletion [89]. Such pollution, however, can hardly be advocated as a method of snail control. The presence of saponins in sisal waste, which, according to this author, appear to be nontoxic to man, seems to warrant a search for molluscicidal activity in other plants of the Agave family. The presence of hecogenin in the juice of sisal has led to increased production of this plant in Tanzania, Kenya and Brazil [19]. Yucca schidigera is molluscicidal [104], but steroidal hecogenins in some Agave species may have a fertility effect on snails $[81,96]$, and wild yucca and agave may grow too slowly for large-scale use [128]. Molasses, a byproduct of sugar refining, was found to act both as a molluscicide and a fertilizer when discharged into the irrigation system of a sugar estate in Tanzania [109]. In Ethiopia, however, concentrations of $5.000 \mathrm{ppm}$ did not affect Biomphalaria snails in the laboratory [31]. The shell of the cashew nut (Anacardium occidentale), in an hexanic extract, killed young and adult $B$. glabrata snails and their eggs at very low concentrations [95]. The active principle is four compounds of anarcadic acid [122], the chemical structure of which has been studied by LLoYd et al. [67]. The waste of other plants, commonly discarded and found to kill snails, such as the leaves of chili pepper (Capsicum frutescens) and tomatoes [82] may prove to be cheap and readily available sources of molluscicides.

In many schistosomiasis endemic areas, the leaves, fruits and nuts of trees and bushes, which have molluscicidal properties, were widely gathered for various purposes by rural populations. For example, the leaves of the leguminous Dichrostachys glomera$t a$, the fruits of which are eaten in tropical Africa, the leaves of Lophira alata, sought for the oil in its nuts, and the leaves of Ximenia americana, a bush used for its fruit throughout tropical Africa [47], are all molluscicidal [5]. Leguminous trees, including species of Acacia, Pithecellobium, Parkia and Prosopis are ideal food plants in semiarid climates, due to their high quality seed protein, drought resistance and minimum cultivation requirements [38] and also exhibit properties toxic to snails. While the complementary use of such xerophytic trees for food and molluscicides should be given greater attention, trees producing edible parts that have also snail-killing properties, including the fruits of Balanites aegyptiaca and Tetrapleura tetraptera, are less likely to be cultivated primarily for snail control in areas where they are a food source or considered sacred. Similarly, the molluscicidal properties of tobacco [102] have little practical application due to high production costs. The study of cercaricidal essential oils in some food plants, including the leaves of green pepper (Capsi- cum annuum) [39], and of cercaricidal and molluscicidal compounds in garden flowers $[43,48]$ has received little attention and may merit further study if prolonged effects can be achieved.

Of the few plants that have been tested in field trials, Phytolacca dodecandra, known as endod in Ethiopia, where its berries are used as the major traditional laundry soap and also as a medicine $[49,53]$ has been studied in depth and can provide a favourable model [59, 137]. Following encouraging field trials in a small lake and in canals of a sugar cane plantation [54] crude ground endod berries in water extract were periodically applied to the streams in Adwa town, northern Ethiopia, during a five-year schistosomiasis control programme. The decrease in the prevalence of $S$. mansoni infection in the 1-5 year age group was attributed to successful snail control [62], but other factors may have been involved. Earlier laboratory studies had shown that the berries, the most potent part of the plant, were highly toxic against all major snail hosts of Schistosoma and Fasciola $[16,57,58,139]$. The active principle of endod is several derivatives of oleanolic acid of a triterpenoid saponin [94]. Its potency is stable within a wide range of $\mathrm{pH}$, temperatures, ultraviolet radiation and following storage for a period of more than five years, but like most other plant and synthetic molluscicdes, it is absorbed in suspended matter $[54,57,58]$. Development of a colorimetric method for quantitative assay of the active substance in treated waterbodies may facilitate application of proper doses in different habitats $[63,66]$. Like many other molluscicides, endod is toxic to tadpoles, schistosome cercariae and miracidia, fish and leeches, but in recent field trials, tadpoles, frogs and aquatic insects were apparently unaffected [72]. Endod is not lethal to the egg masses of snail hosts at molluscicidal concentrations, which is a marked disadvantage, as to provide effective results "the frequency of snail operations must be doubled" [80], this in turn increasing fish kill and probably the magnitude of other ecological disturbances. Its mammalian toxicity appears to be comparable to many other saponin plants $[41,54,58$, 77]. No permanent plant toxicity was noted during continuous application of high concentrations to local plants grown experimentally [143], and no mutagenicity was detected during a preliminary restricted study using a bacterial plate test devided by AMES [55]. To date the chronic toxicity of endod has not been adequately investigated [80].

The water/fermentation extraction process recently developed at the Institute of Phathobiology in Addis Ababa [64] eliminates the need for elaborate extraction and drying apparatus earlier used in the more expensive butanol extraction process, at the same time yielding a molluscicide with comparable potency (4 ppm) [64]. The sevenfold increase in potency of the water/fermentation extract, in comparison with 
the crude berries, may, once large-scale cultivation of endod takes place, reduce its cost for snail control to a level where it could become competitive with Bayluscide ${ }^{\circledR}$, at present the only synthetic molluscicide in use [80]. During the schistosomiasis control project in Adwa, crude endod berries were bought in local markets, no comparative cost estimates were made, but the cost of the programme was US $\$ 0.03$ per head of the population [62]. The cultivation of selected strains with berries that are molluscicidal at 5 ppm may permit their application without extraction in the future. Lugr [68] estimated that $1.0-1.5$ ha of $P$. dodecandra selected types are sufficient to treat 10.000 ha of irrigated sugar cane. In recent field trials, involving the use of high potency strains, only $2.2-3.5 \mathrm{~kg}$ crude endod powder were required to treat effectively 300 metre stretches of two small Ethiopian streams per application [72].

The use of the water/fermentation extraction process for other purpose is being investigated, and studies are underway to develop methods to extract secondary constituents of the endod berries for use in various products. These may include antifertility and contraceptive agents [121], antiviral, antibacterial, antifungal and antihelminthic compounds [60, 138], unsecticides and larvicides against houseflies and species of Simulium, the vector of river blindness, and Anopheles mosquitoes [13, 61, 119], industrial detergents, drying regulators in cement and anticholesterol medicines [76, 92]. Such additional uses may solve the problem of the low and seasonal demand for endod as a molluscicide.

Apart from the unresolved reservations concerning the chronic toxicity of endod to non-target organisms, including man, a major constraint in the wide use of the berries of this plant in snail control programmes has been failure to grow $P$. dodecandra on a large scale until the late 1970 's, due mainly to the low demand for molluscicides in Ethiopia, as well as insufficient knowledge of its growth requirements in different soils and climates, and its susceptibility to pests. Several species of insects attack the leaves and shoots, and nematodes the roots $[72,125]$. After obtaining promising results, LuGT [72] recommended the cultivation of insect-resistant strains of endod. In Ethiopia the endod bush grows naturally only in the cool, humid highlands above ca. $1500 \mathrm{~m}$, and has only recently been planted for field trials in the hot, arid lowlands, where schistosomiasis is most prevalent [50]. Whereas technical problems of endod cultivation may be largely solved through selection and breeding of hardy and disease-resistand varieties, and by proper crop management $[72,84]$, the question of low demand for molluscicides in Ethiopia is more serious. Regular application of molluscicides in Ethiopia is presently confined to the Wonji-Shoa sugar cane irrigation scheme, the only farm where endod is grown on a large scale. In 1970, 1301 of Frescon ${ }^{\circledR}$ and
$250 \mathrm{~kg}$ of Bayluscide ${ }^{\circledR}$ were applied experimentally over part of that farm at a cost of nearly US $\$ 4000$ [31]. Failure to treat other irrigation schemes reflects prevailing health policy priorities and the poor economy of Ethiopia. These constraints may well curtail further research on several other potential plant molluscicides in that country, including the leaves of Sesbania sesban [127], and the leaves and stems of Withania somnifera, a household medicine [49] which also contains an antitumor and antiarthritic steroid lactone [40]. The occurrence of $P$. dodecandra throughout Africa [133], and of several other species of Phytolac$c a$ in Central and South America and Asia [29, 52, 95], may stimulate further studies on the byproducts of species and strains of this genus.

The annual herb Ambrosia maritima is known under the vernacular name damsissa in Egypt, where it occurs throughout the Nile valley and delta [123]. This plant has been studied at Alexandria University for more than 25 years for use in community-level snail control programmes. Its flowering parts and leaves are moderately molluscicidal, and alcoholic extracts do not increase potency $[113,114]$. The extracted active substances damsin, ambrosin and tribromo-damsin [3] proved to be highly molluscicidal. Damsissa is non-toxic to cattle and sheep, which commonly graze on this plant, to fish and apparently to man, who traditionally used concoctions and infusions from the flowering parts as an antispasmodic in colics, as a diuretic [113], and as a remedy for haematuria in Schistosoma haematobium infection [51]. In field trials, significant reductions in snail populations were achieved when whole damsissa plants were placed into canals [115], and also by growing the plant on canal banks where the fluctuating water leached out the active principle from the flowering parts and leaves [34]. This method of natural control resembles that earlier advocated by ArChibald [12], Wagner [131] and ANANTARAMAN [11], who proposed that fruit and leaves with molluscicidal properties, falling from trees planted along water courses, might control snail host populations. In spite of this desirable feature of damsissa, and the fact that its flowering period coincides with the seasonal peak of schistosomiasis transmission in Egypt, there are serious constraints, mostly associated with ecological pressures, which curtail its usefulness. In addition to growing poorly along drainage canals due ot its poor adaption to saline soils [34], it is damaged by grazing livestock and its habitat has been drastically reduced since the end of the annual Nile flood $[33,120]$. Moreover, this small, prostrate plant is commonly destroyed during mandatory canal cleaning operations. Damsissa has not been grown in sufficient quantities for self-reliant community snail control programmes and, as already mentioned, the great land pressure in Egypt would tend to prohibit its cultivation in plots. The relatively low molluscicidal activity of the water extracts, the high 
cost of extracting the active principle, their instability under simulated field conditions [116] and, not least, the widespread occurrence of host snails in the extensive irrigation networks of Egypt further diminish its usefulness in snail control. The recent discovery of saponin plants in Egypt [2,111], the use of natural products with molluscicidal properties by Egypt's pharmaceutical industry [136], and the presence of several well stocked herbaria in Cairo may encourage the search for other, more suitable plants.

The seeds of Croton macrostachys, used as a purgative and antihelminthic in Sudan, where it is known as habat-el-mollok, were recently screened for molluscicidal activity by DAFFALA and AMIN [28]. The results of the comparative laboratory tests show that habat-el-mollok seeds are more toxic than crude endod berries. Molluscicidal potency of the water extract was not affected by $\mathrm{pH} 4-10$ or by storage for six days; it increased with temperature, but rapidly declined with increasing turbidity. Several species of fish were killed at molluscicidal concentrations, but its mammalian toxicity was acceptable and no phytotoxicity was detected. Field application of the water extract at $2 \mathrm{ppm}$ controlled snails in a stagnant canal for three months. Aquatic plants and most fauna were not affected. The use of only six kilos of the seed for treatment of $3000 \mathrm{~m}^{3}$ of canal water [28] compares favorably with endod, but in a laboratory experiment by LuGT [72] in which $C$. macrostachys seeds from Khartoum markets were used, no molluscicidal activity was observed. Preliminary studies of its chemistry show that saponins constitute the active substance, but the presence of alkaloids [28] requires that the seeds be further studied for non-target toxicity. This is all the more necessary as Sudanese people consider habat-el-mollok to be highly toxic to humans, and because the related $C$. tiglium, also known under this vernacular name in Sudan [28], is carcinogenic.

The low molluscicidal potency of the fruit of Sapindus saponaria, which required the application of $1 \mathrm{~kg}$ of fruit per $\mathrm{m}^{3}$ of water in a pond in Zanzibar [88], tends to limit its use to small waterbodies, many of which may be important schistosomiasis transmission sites in certain areas of East Africa [79]. Scarcity of this plant in endemic areas will require that it be planted near snail habitats, if only to minimize transport costs.

Peirera et al. [97] studied the stem of Euphorbia cotonifolia, an ornamental plant in Brazil. The fractioned hexanic extract was highly toxic to Biomphalaria glabrata and its eggs in the field, but killed fish at lower dosage levels.

The tuberous root of Neorautanenia pseudopachyrhizus, a common herbaceous plant on the East African coast, was found to cause more than 50 percent mortality in Bulinus (P.) globosus when applied in a pool in Kenya at a concentration of about 500 $\mathrm{ppm}$. At that concentration it was not piscicidal and was well tolerated by monkeys [126]. This author suggested that the plant be cultivated near snail habitats to minimize transport of the heavy and bulky roots, the major disadvantage associated with its use.

In Nigeria encouraging results were obtained with the aqueous and methanolic extracts of Tetrapleura tetraptera. In a schistosomiasis control project at $\mathrm{Fa}$ sina and Abun-Abon the methanolic extract was stable under field conditions and had little mammalian toxicity and no phytotoxicity [6]. Another Nigerian medicinal plant of the Mimosa family, Calliandra portoricensis, was highly piscicidal [4].

The seeds of the Brazilian leguminous tree, Pithecellobium multiflorum, are highly active against Biomphalaria adults and eggs [106, 107]; they may be another promising plant molluscicide and should be field tested.

\section{Summary and Conclusions}

Research on plant molluscicides is gaining support at a time of slow growth in synthetic molluscicides. During the past 50 years, more than 1000 plant species have been screened, most of them superficially, for molluscicidal activity. The richness of the flora in most areas where snail-transmitted diseases are endemic, suggests that many plants with molluscicidal properties remain to be discovered. The recently developed computerized information system NAPRALERT (Natural Products Alert), designed to bring together the world literature with regard to plant, animal, microbial and marine organisms, represents a valuable aid in the search for molluscicidal plants. This system, supported by the World Health Organization, provides ethnomedical information, biological data for extracts and the isolation or identification of secondary constituents with their appropriate literature citations [37]. Botanical descriptions in herbals and herbaria and anthropological accounts of plant use [112] as well as herbalists [5] and market surveys [32, 49], can provide additional leads.

The desirable characteristics of plant molluscicides are listed in Table I. Several promising plants have already been identified. Endod (Phytolacca dodecandra), in particular, compares fairly well with the major synthetic molluscicides in terms of potency, and has the advantage of yielding other products of pharmaceutical and industrial interest. However, its chronic toxicity is unknown and its use under most field conditions is, therefore, precluded.

The use of plant molluscicides may not only eliminate the expense of importing costly synthetic molluscicides, but could also stimulate growth of small-scale industries in developing countries. More emphasis, however, must be placed even from the beginning on agronomic and organizational aspects, including community participation, if plant molluscicides are 


\section{Table I}

Desirable characteristics of molluscicidal plants

Toxicity High toxicity against target organisms; low or no toxicity against non-target organisms at molluscicidal concentrations.

Supply Readily available locally

Yield High yield of molluscicidal material per plant and per unit area of cultivated land.

Type of plant Perennial rather than annual; reproduce by seeds rather than by tubers; drought resistant for use in arid areas; semiaquatic or aquatic for use directly in snail habitats; high propagation and rapid growth rates with minimum capital and labour input; high adaptability to differing local environmental conditions; high resistance to pests, weeds etc.

Plant parts Localization of high potency levels in regenerating parts (berries, fruits, flowers, nuts, deciduous leaves) or vegetatively planted tubers.

Storage Molluscicidal material of seasonally producing plants should not lose potency during storage of at least one year

Extraction Active principle should be extractable by simple apparatus and commonly available solvents, preferably water

Physio- Retention of molluscicidal potency under physiochemical chemical influences $(\mathrm{pH}$, sunlight, temperatures, stability silt, organic matter, water pollution) normally found in the endemic area during the annual cycle.

Knowledge of A good knowledge of growing habits and requireplants in ments, toxicity and any medicinal properties of endemic area plants by local people, is an asset.

Cultural Absence of spiritual and ceremonial uses of plants acceptability and aversions based on folklore and magic, which might interfere with their use for snail control, is desirable.

Additional Suitability of the same plant parts for other public uses health, local, domestic or industrial uses.

to be applied successfully in long-term and self-sustained snail control programmes.

Major constraints presently limiting the use of plant molluscicides are lack of adequate information on their cost-effectiveness and chronic toxicity, and difficulties of developing viable snail control programmes in rural areas using local resources. Snail control has traditionally been carried out, using imported synthetic chemicals, with minimum or no involvement of local people, by health officials and tech- nicians of central governments and international organizations. The very nature of natural products, processed and applied in the country of origin, makes it imperative that governments, research institutes and rural communities undertake collaborative programmes designed to screen, cultivate, apply and monitor effects of carefully selected plant products. Costs will be highest during the initial development phases, but use of local labour for cultivating, harvesting, processing and applying plant molluscicides, reduced transportation costs and new methods of screening and extracting active compounds, can make them more cost-effective. The extensive knowledge most rural people have of local plants with toxic and medicinal properties, together with new information on chemotaxonomy, will permit focused screening of those families and genera that are most likely to contain species suitable for effective snail control.

Although several research programmes have successfully tested plant materials, using techniques commonly used in phytochemical and pharmacological studies, more effective exchange of information is needed do develop specific research methodologies and snail control strategies. It is clear that more integrated laboratory and field trials, including acute and chronic toxicity studies, the evaluation of plants for cultivation under diverse local conditions, and their suitability for exploitation by intermediate technologies, are urgently needed.

Perhaps there is need to emphasize that the methods used for biological and chemical screening of plants have lacked standardization. Many have been inadequate, contributing to unexplained variations in results reported by different scientists in respect to the same plant species, and consequently impeding efforts to assess their true impact on ecosystems. Screening and evaluation methods developed by the World Health Organization [134, 135] should be used.

In future, more attention must be paid to the development of simple, cheap and efficient extraction and application techniques amenable for use in rural communities. With community development and appropriate technology becoming an important element in revised national socio-economic planning, many endemic countries can now support, with justification, the development and evaluation of plant molluscicides as a new tool in the implementation of internally directed and properly sustained health improvement campaigns. 
Table II

Summary of toxicity studies

\begin{tabular}{|c|c|c|c|c|c|c|}
\hline $\begin{array}{l}\text { Plant species, } \\
\text { by family }\end{array}$ & $\begin{array}{l}\text { Parts tested } \\
\left.\text { (extract }^{\star}\right)\end{array}$ & $\begin{array}{l}\text { Concentration } \\
\text { tested } \\
\text { (time of exposure) }\end{array}$ & $\begin{array}{l}\text { Mortality } \\
(\%)\end{array}$ & Target species & Other effects & $\begin{array}{l}\text { Refer- } \\
\text { ences }\end{array}$ \\
\hline
\end{tabular}

\section{AGAVACEAE}

Agave sisalana

Leaf $(W)$

\section{ALPINACEAE}

Hedychium coronarium Seeds (W)

ANACARDIACEAE

Anacardium occidentale

Anacardium occidentale

Anacardium occidentale

Anacardium occidentale

Anacardium occidentale

Anacardium occidentale

Shell (SM)

Shell $(H)$

Shell $(H)$

Shell $(H)$

Shell $(H)$

Shell $(H)$

\section{ANNONACEAE}

Annona senegalensis

Rauvolfia caffra

ASCLEPIADACEAE

Cryptostegia grandiflora

BOMBACEAE

Bombax costatum

CAESALPINIACEAE

Dalium guineense

CANNACEAE

Cannaindica

Canna indica

Canna indica

CHARACACEAE

Chara vulgaris

COMBRETACEAE

Combretum spp.

Terminalis mollis

COMPOSITAE

Ambrosia maritima

Ambrosia maritima

Ambrosia maritima

Ambrosia maritima

Ambrosia maritima

Ambrosia maritima

\section{CORNACEAE}

Cornus florida
Stem (M)

$\operatorname{Root}(\mathrm{M})$

Stem (M)

Root, stem (M)

Fruit (M)

Whole plant (W)

Whole plant (Er)

Root, leaves (M)

Whole plant

(in aquaria)

Stem, $\operatorname{root}(\mathrm{M})$

Root (M)

Flowers,

leaves (W)

Flowers, leaves (hot A)

Flowers, leaves

(W)

Flowers, leaves (W)

Damsin, ambrosin and tribromo damsin $(S, A, C, E)$ Flowers, leaves (W, field trial)

Bark (M)
$5000 \mathrm{ppm}(24 \mathrm{hr})$

90

B.(P.) globosus

Destroys most

91 aquatic fauna and flora

$\begin{array}{ll}25 \mathrm{ppm}(24 \mathrm{hr}) & 100 \\ & \\ 0.35 \mathrm{ppm}(24 \mathrm{hr}) & 50 \\ 0.6 \mathrm{ppm}(24 \mathrm{hr}) & 50 \\ 1.4 \mathrm{ppm}(24 \mathrm{hr}) & 50 \\ & \\ 18 \mathrm{ppm}(24 \mathrm{hr}) & 50 \\ 1 \mathrm{ppm}(1 \mathrm{hr}) & 50 \\ 3 \mathrm{ppm}(24 \mathrm{hr}) & 20\end{array}$

$100 \mathrm{ppm}(24 \mathrm{hr})$

85

$100 \mathrm{ppm}(24 \mathrm{hr})$

100

$100 \mathrm{ppm}(24 \mathrm{hr})$

100

100 ppm (24 hr)

100

$100 \mathrm{ppm}$ (24 hr)

100

B. globosus

$820 \mathrm{ppm}(24 \mathrm{hr})$

$170 \mathrm{ppm}(24 \mathrm{hr})$

98

B. alexandrina

$100 \mathrm{ppm}(24 \mathrm{hr})$

$B$. alexandrina

$5-10$

B. (P.) globosus

Plants in aquaria

100

B. glabrata

$100 \mathrm{ppm}(24 \mathrm{hr})$

100

B. globosus

100 ppm (24 hr)

100

B. globosus

$1000 \mathrm{ppm}(12,24 \mathrm{hr})$

30,100

Bulinus sp.

2000 ppm (24 hr)

0

Biomphalaria sp.

$1000 \mathrm{ppm}(48 \mathrm{hr}) \quad 100$

1000 ppm (30 min) $100(?)$

S. haematobium eggs Not studied

S. haematobium Not studied

miracidia and

cercariae

$9.7-14.5(24 \mathrm{hr}) \quad 90$

B. alexandrina,

$B$. truncatus

Approx. 70 ppm (?)

Reduction

B. alexandrina in snails for $B$. truncatus 7 weeks.

$100 \mathrm{ppm}(24 \mathrm{hr})$
113,114

113,114

Not studied $\quad 122$

No toxicity in mice 95

Not studied $\quad 95$

Not studied $\quad 95$

Not studied $\quad 95$

95

5

5

5

5

5

75

Not studied $\quad 75$

Not studied $\quad 5$

Not studied $\quad 103$

Not studied $\quad 5$

No effect on $\quad 113$

ia nilotica, and Culex larvae

113,114

Not studied $\quad 116$

No fish toxicity

115,34 noted

Not studied

45
"Mollusci- B. glabrata cidal" 
Table I Cont

Plant species

Parts tested

Concentration

Mortality Target species

Other effects

Refer-

by family

(extract ${ }^{\star}$ )

tested

$(\%)$

ences

(time of exposure)

\section{CUCURBITACEAE}

Luffa operculata

EUPHORBIACEAE

Bridelia adroviridis

Croton macrostachys

Croton macrostachys

Croton macrostachys

Croton macrostachys

Croton macrostachys

Seeds (W)

Seeds (W)

Seeds (W)

Seeds $(W)$

Croton macrostachys

Croton macrostachys

Croton macrostachys

Croton macrostachys

$\begin{array}{ll}\text { Croton tiglium } & \text { Seeds }(\mathrm{W}) \\ & \\ \text { Croton tiglium } & \text { Seeds }(\mathrm{W}) \\ \text { Croton tiglium } & \text { Seeds }(\mathrm{Er}) \\ \text { Croton tiglium } & \text { Seeds } \\ & \text { (W, field trial) } \\ \text { Croton tiglium } & \text { Seeds }(\mathrm{W}) \\ & \\ \text { Cyrptogonone argentea } & \text { Root }(\mathrm{M}) \\ \text { Euphorbia cotonifolia } & \text { Leaves }(\mathrm{H}) \\ \text { Euphorbia cotonifolia } & \text { Leaves }(\mathrm{H}) \\ & \\ \text { Euphorbia cotonifolia } & \text { Leaves }(\mathrm{H}) \\ \text { Euphorbia cotonifolia } & \text { Leaves }(\mathrm{H}) \\ & \\ \text { Euphorbia cotonifolia } & \text { Leaves }(\mathrm{H}) \\ & \\ \text { Euphorbia cotonifolia } & \text { Leaves }(\mathrm{H}) \\ \text { Euphorbia lactea } & ?(\mathrm{E}) \\ \text { Euphorbia lactea } & ?(\mathrm{~B}) \\ \text { Euphorbia lactea } & ?(\mathrm{P}) \\ \text { Euphorbia lactea } & ?(\mathrm{Er}) \\ \text { Euphorbia lactea } & ?(\mathrm{Be}) \\ \text { Jatropha curcas } & \text { All parts }(\mathrm{W}) \\ \text { Jatropha curcas } & \text { Seeds }(\mathrm{W}) \\ \text { Jatropha curcas } & \text { Seeds }(\mathrm{M}) \\ \text { Jatropha curcas } & \text { Seeds }(\mathrm{B}) \\ \text { Jatropha curcas } & \text { Seeds }(\mathrm{C}) \\ \text { Jatropha curcas } & \text { Seeds }(\mathrm{Be}) \\ \text { Jatropha curcas } & \text { Seeds }(\mathrm{W}) \\ & \\ \text { Jatropha curcas } & \text { Root }(\mathrm{W}) \\ \text { Jatropha curcas } & \text { Root }(\mathrm{A}) \\ \text { Jatropha curcas } & \text { Seeds }(\mathrm{W}) \\ \text { LEGuMINOSAE } & \text { field trial) } \\ \text { Derris elliptica } & \text { Root }(\mathrm{W}) \\ \text { Entada phaseoloides } & \text { Bark }(\mathrm{B}) \\ & \end{array}$

(W, field trial)

Seeds (W)

Seeds $(W)$

Seeds (W)

Seeds

Seeds $(W)$

Seeds

(W, field trial)

Root (M)

Leaves $(\mathrm{H})$

Leaves $(H)$

(H)

$1000 \mathrm{ppm}(24 \mathrm{hr})$
$100 \mathrm{ppm}(24 \mathrm{hr})$
$1.0 \mathrm{ppm}(24 \mathrm{hr})$

60

B. stramina

Not studied

117

90

B. globosus

B. truncatus,

Lymnaea sp.

$90 \quad$ B. pfeifferi

90 B. glabrata

$100(?)$

Eggs of $B$. pfeifferi

(late stage)

No effect Cercariae and

miracidia of

S. mansoniand

S. haematobium

$$
\begin{array}{r}
45 \mathrm{ppm}(24 \mathrm{hr}) \\
20 \mathrm{ppm}(24 \mathrm{hr}) \\
1 \mathrm{ppm}(24 \mathrm{hr}) \\
2 \mathrm{ppm}(24 \mathrm{hr})
\end{array}
$$

50

Tilapia nilotica

50

Gambusia affinis

Rat (Arvicanthis

niloticus)

Snails

B. truncatus

controlled

for 3

months

$\begin{array}{lll}0.7 \mathrm{ppm}(48 \mathrm{hr}) & 50 & \text { O. quadrasi } \\ & & \\ 0.007 \mathrm{ppm}(48 \mathrm{hr}) & 50 & \text { Fish (Oryzias latipes) } \\ 0.09-1.0(48 \mathrm{hr}) & 50 & \text { O. quadrasi } \\ 4 \mathrm{~g} / \mathrm{m}^{2}(?) & 90+ & \text { O. quadrasi }\end{array}$

Not studied

Not studied

Not studied

28

28

28

Several species

28

fish killed;

no phytotoxicity

noted

Skin irritant in

141

paste form

Not studied

Not studied

141

141

141

$1.6 \mathrm{~g} / \mathrm{kg}$ of
body weight (?)

$100 \mathrm{ppm}(24 \mathrm{hr}) \quad 100 \quad$ B. globosus

$1.2-3.4 \mathrm{ppm}(24 \mathrm{hr}) \quad 90$

Adult B. glabrata

$4.8-8.0 \mathrm{ppm}(24 \mathrm{hr}) \quad 90$

Newly hatched

Not studied

141

Not studied

Not studied

Not studied

B. glabrata

13-48 ppm (24 hr) $90 \quad$ B. glabrata eggs

$6 \mathrm{~g} / \mathrm{kg}$ of

No effects Mice

Not studied

Not studied

body weight

2.5 ppm ( $24 \mathrm{hr})$

100

Fish

Not studied

(Lebistes reticulatus)

$9.6 \mathrm{ppm}(24 \mathrm{hr}) \quad 100 \quad$ S. mansonicercariae

$2.4 \mathrm{ppm}(?)$

$9.8 \mathrm{ppm}(?) \quad 50$

B. alexandrina

B. alexandrina

$5 \mathrm{ppm}(?)$

4 ppm (?)

$4.8 \mathrm{ppm}(?)$

$$
50
$$

B. alexandrina

50

B. glabrata

$50 \quad$ B. alexandrina

$1000 \mathrm{ppm}(24 \mathrm{hr})$

No effects

Lymnaea cubensis

$27.5-48.5(48 \mathrm{hr}) \quad 90 \quad 0 . q u a d r a s i$

$6.7 \mathrm{ppm}(48 \mathrm{hr}) \quad 50 \quad$ O.quadrasi

$45 \mathrm{ppm}(48 \mathrm{hr}) \quad 50 \quad$ O.quadrasi

$65 \mathrm{ppm}(48 \mathrm{hr}) \quad 50 \quad$ O.quadrasi

$40 \mathrm{ppm}(48 \mathrm{hr}) \quad 50 \quad$ O.quadrasi

$10 \mathrm{~g} / \mathrm{kg}$ of body No effects Mice

Not studied

Not studied

Not studied

Not studied

Not studied

Not studied

Not studied

Not studied

Not studied

Not studied

Not studied

Not studied

Not studied

Not studied

Not studied

Not studied

Not studied

Not studied

5

\section{8}

28

28

28

28

1

weight (one dose)

$\begin{array}{ccc}160(24 \mathrm{hr}) & 50 & \text { B. truncatus } \\ 100(24 \mathrm{hr}) & 100 & \text { B. truncatus } \\ 4 \mathrm{~g} / \mathrm{m}^{2} \text { (2weeks) } & 90+ & \text { O. quadrasi }\end{array}$

$20 \mathrm{ppm}(24 \mathrm{hr}) \quad 100 \quad$ B. (P.) globosus

B. (P.) globos
O. quadrasi

\section{5}

97

97

97

97

97

97

2

2

2

2

2

82

142

142

142

142

142

142

32

32

142 
Table I Cont.

Plant species,

by family
Parts tested

(extract*)
Concentration

tested

(time of exposure)
Mortality Target species

(\%)
Other effects

Refer-

ences

\section{Entada phaseoloides}

Entadaphaseoloides

Entadaphaseoloides

Neorautenenia

pseudopachyrhizus

Neorautenenia

pseudopachyrhizus

Piptadenia macrocarpa

Pithecellobium multifloru

Stenolobium velutinum

Stenolobium velutinum

MALPIGUIACEAE

Brysonima sericeae

MIMOSACEAE

Acacia dudgeoni

Calliandra portoricensis

Distrochachys glomerata

Tetrapleura tetraptera

Tetrapleura tetraptera

\section{OCHNACEAE}

Lophira alata

OLACACEAE

Ximenia americana

OPILIACEAE

Agonandra brasiliensis

Agonandra brasiliensis

PHYTOLACCACEAE

Phytolacca dodecandra

Phytolacca dodecandra

Phytolacca dodecandra

Phytolacca dodecandra

Phytolacca dodecandra

Phytolacca dodecandra

Phytolacca dodecandra

Phytolacca dodecandra

Phytolacca dodecandra

Phytolacca dodecandra

Phytolacca dodecandra

Phytolacca dodecandra

Phytolacca dodecandra

Phytolacca dodecandra Phytolacca dodecandra Phytolacca dodecandra Phytolacca dodecandra Phytolacca dodecandra Phytolacca dodecandra
Bark, (E, B, EA, W) $500+(48 \mathrm{hr})$

Bark (B)

Bark (B,

field trial)

Root (W)

Root (W,

field trial)

Bark (W)

Seeds (W)

Bark, leaves (W)

Branches,

fruit (W)

Bark (W)

Leaves (M)

Root (M)

Leaves (M)

Fruit (M)

Fruit (W)

Leaves (M)

Leaves (M)

Bark (W)

Bark, root (A)

Berries

(dry fruit) (W)

Berries (B)

Berries (B)

Berries (B)

Berries (W)

Berries (W)

Berries (W)

Berries (W)

Berries (W)

Berries (W)

Berries (W)

Berries (W)

Berries (B)

Berries (B)

Berries (B)

Berries (B)

Berries (B ?)

Berries (B)

Berries (B)

$1000 \mathrm{ppm}(8 \mathrm{hr})$
$100 \mathrm{ppm}(24 \mathrm{hr})$
$20 \mathrm{ppm}(24 \mathrm{hr})$
$100 \mathrm{ppm}(24 \mathrm{hr})$
$1-3 \mathrm{ppm}(24 \mathrm{hr})$
$10 \mathrm{ppm}(?)$

$\begin{array}{llll}50 & \text { O.quadrasi } & \text { Not studied } & 140 \\ 50 & \text { Fish (Oryzias latipes) } & \text { Not studied } & 140 \\ 22-50 & \text { O.quadrasi } & \text { Not studied } & 140\end{array}$

$\begin{array}{rrl}500 \mathrm{ppm}(24 \mathrm{hr}) & 100 & B .(P .) \text { globosus } \\ 73.5 \mathrm{lbs} / & & \\ 2350 \mathrm{~m}^{3} \text { of water } & 50 & \text { B. }(P .) \text { globosus } \\ 1000 \mathrm{ppm}(24 \mathrm{hr}) & 100 & \text { B. glabrata } \\ 100 \mathrm{ppm}(24 \mathrm{hr}) & 90 & \text { B. stramina } \\ 1000 \mathrm{ppm}(24 \mathrm{hr}) & 100 & \text { B. glabrata } \\ 1000 \mathrm{ppm}(72 \mathrm{hr}) & 100 & \text { B. stramina }\end{array}$

Not studied

126

Not studied

Not studied

Not studied

Not studied

Not studied

126

10

106

10

10

100

B. stramina

Not studied

117

100 B.globosus

100 B.globosus

100 B.globosus

„mollusci- B.globosus

cidal"

„mollusci- B. globosus,

cidal" Lanistessp.,

B. forskalii

Not studied

Not studied

Not studied

Not studied

40

0 年 
Table I Cont.

Plant species, by family
Parts tested

(extract ${ }^{\star}$ )
Concentration tested

(time of exposure)
Mortality Target species

(\%)
Other effects

Refer-

ences

\begin{tabular}{lll}
\hline $\begin{array}{l}\text { Phytolacca dodecandra } \\
\text { Phytolacca dodecandra }\end{array}$ & $\begin{array}{l}\text { Berries (B) } \\
\text { Berries (water/ } \\
\text { fermentation) }\end{array}$ & $\begin{array}{l}5.9 \mathrm{ppm}(24 \mathrm{hr}) \\
4 \mathrm{ppm}(24 \mathrm{hr})\end{array}$ \\
$\begin{array}{c}\text { Phytolacca dodecandra } \\
\text { Berries (W, } \\
\text { field trial) }\end{array}$ & $\begin{array}{l}50-100 \mathrm{ppm} \\
(3-6 \mathrm{hr})\end{array}$ \\
& $\begin{array}{l}\text { Berries (W, } \\
\text { Phytolacca dodecandra }\end{array}$ & $\begin{array}{l}80-100 \mathrm{ppm} \\
(6-8 \mathrm{hr})\end{array}$
\end{tabular}

Phytolacca isocan
Phytolacca rivinoid
PIPERACEAE
Piper tuberculatum

Rootbark

$10 \mathrm{ppm}(24 \mathrm{hr})$

"mollusci- B. glabrata

Not studied

POLYGALACEAE

Securidaca

Root (W)

350 ppm (24 hr)

100

Taphia (sic) glabrata

Not studied

POLYGONACEAE

Leaves (W)

5000 ppm (24 hr)

„mollusci- B. pfeifferi,

dal"

L. natalensis

Polygonum senegalense

Seeds, leaves $(E)$

$25 \mathrm{ppm}(8 \mathrm{hr})$

100

B. pfeifferi,

Not studied

30

RHAMNACEAE

Maesopsis emenii

ROSACEAE

Acioa spp.

RUBIACEAE

Morinda lucida

Randia nilotica

$\operatorname{Root}(\mathrm{M})$

Stem (M)

$100 \mathrm{ppm}(24 \mathrm{hr})$

100

B. globosus

Not studied

Leaves (M)

$100 \mathrm{ppm}(24 \mathrm{hr})$

100

B. globosus

Not studied

100 ppm (24 hr) 100

B. globosus

Not studied

Fruit $(S: P, E)$

$60 \mathrm{ppm}(24 \mathrm{hr})$

100

B. pfeifferi

$20 \mathrm{ppm}(24 \mathrm{hr})$

B. truncatus

Root bark (S:P, E)

$80 \mathrm{ppm}(24 \mathrm{hr})$

100

B. pfeifferi

$40 \mathrm{ppm}(24 \mathrm{hr})$

100

B. truncatus

B. pfeifferi

Root bark (W)

$40 \mathrm{ppm}$ (24 hr)

B. truncatus

B. pfeifferi

Rothmania whitefieldii

SAPINDACEAE

Paullinia pinnata

Paullinia pinnata

Sapindus saponaria

Sapindus saponaria

Sapindus saponaria

Sapindus saponaria

Sapindus saponaria

Sapindus saponaria

Leaves, stem (M)

$100 \mathrm{ppm}(24 \mathrm{hr})$

100

100

B. globosus

Bark, leaves (W) 1000 ppm (24 hr)

100 B. glabrata

All parts (W)

$1000 \mathrm{ppm}(24 \mathrm{hr})$

Berries (W)

Berries (W)

Berries

(hot W, A)

Berries (hot W, A) 25 ppm (6 hr)

Berries (hot W, A) $25 \mathrm{ppm}(6 \mathrm{hr})$

Berries (hot, W, A) $25 \mathrm{ppm}(6 \mathrm{hr})$

$\begin{array}{ll}\text { Sapindus saponaria } & \begin{array}{l}\text { Berries } \\ \text { (hot W, A) }\end{array} \\ \text { Sapindus saponaria } & \text { Berries (W) }\end{array}$

$40-50 \mathrm{ppm}(6 \mathrm{hr})$

Lethal

L. cubensis,

L. columella

$100 \mathrm{ppm}(40 \mathrm{hr})$

$150 \mathrm{ppm}(24 \mathrm{hr})$

B. (P.) globosa

100

B. (P.) globosa

Not studied

5

B. glabrata,

Notstudied

86

94

L. cubensis

10017 species of Protozoa Not studied 129

60-100 3 species of Crustacea Not studied 129

No effects Anophelessp., $\quad$ Not studied 129

Culex sp., 11 other insect species tus, Rivulus bondi) 
Table 1 Cont.

Plant species,

by family
Parts tested

(extract ${ }^{*}$
Concentration

tested

(time of exposure)
Mortality Target species Other effects

(\%)
Refer-

ences
Sapindus saponaria

Sapindus saponaria

\section{SOLANACEAE}

Solanum nodiflorum

Solanum nodiflorum

Solanum nodiflorum

Solanum nodiflorum

Solanum nodiflorum

Solanum nodiflorum

\begin{tabular}{|c|c|}
\hline Solanum mammosum & Fruits (M) \\
\hline $\begin{array}{l}\text { STYRAXAXEAE } \\
\text { Styrax officinalis } \\
\text { UMBELLIFERAE }\end{array}$ & Fruit (?) \\
\hline $\begin{array}{l}\text { Amnimajus } \\
\text { VERBENACEAE }\end{array}$ & ? \\
\hline $\begin{array}{l}\text { Vitex oxycuspis } \\
\text { XYRYDACEAE }\end{array}$ & Stem (M) \\
\hline $\begin{array}{l}\text { Xiris anceps } \\
\text { ZYGOPHYLLACEAE }\end{array}$ & Leaves (M) \\
\hline Balanites aegyptiaca & Fruit (W) \\
\hline Balanites aegyptiaca & Fruit (W) \\
\hline Balanites aegyptiaca & Fruit (W) \\
\hline Balanites aegyptiaca & Bark (W) \\
\hline Balanites aegyptiaca & $\begin{array}{l}\text { Fruit (W, } \\
\text { field trial) }\end{array}$ \\
\hline Balanites aegyptiaca & Fruit (M) \\
\hline Balanites maughamii & Fruit (W) \\
\hline
\end{tabular}

Berries (W,

field trial)
Berries (W)

500 ppm (24 hr)
$1 \mathrm{~kg}$ fruit pulp/m
water

All parts (W)

100 ppm (24 hr)

Roots, leaves (W)

Roots, leaves (W)

Roots, leaves $(W)$

Roots, leaves (W)

Roots, leaves (W)

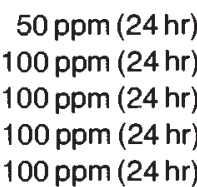

$100 \mathrm{ppm}(24 \mathrm{hr})$

$25 \mathrm{ppm}(24 \mathrm{hr})$

100 ppm (24 hr)

$2 \mathrm{ppm}(?)$

100 ppm (24 hr)

100 ppm (24 hr)

$5.2 \mathrm{~g} / 30$ liters of

water (12 hr)

$5.2 \mathrm{~g} / 30$ liters of $100(?)$

water (1 hr or less)

1:860 (48 hr)

1:2600 (1 week)

Fruits dropped

from trees (?)

100 ppm (24 hr)

1 fruit/100000 cc of water $(24 \mathrm{hr})$
100

$\begin{array}{ll}100 & \text { B. }(P .) \text { africanus } \\ \text { Snail } & \text { B. }(\boldsymbol{P} \text {.) africanus } \\ \text { reduction } & \end{array}$

for 10 days

100
100
100
100
85
No effect

L. cubensis,

L. columella

L. columella

B. glabrata

L. cubensis

Physa cubensis

Noeflect

Marisa cornuarietis,

Tarebiagranifera

$95 \quad$ L. cubensis

100

Bulinus sp.

9-69 Biomphalariasp.

100

B. globosus

B. globosus

100

Bulinus planorbis

(sic)

S. haematobium

cercariae

100

B. glabrata(?)

B. glabrata (?)

$15-75$

B. glabrata (?)

100

B. globosus

Mollusci-

cidal
B. (P.) africanus,

L. natalensis
Not studied

Not studied

88

88

32

Notstudied

83

Not studied $\quad 83$

Not studied $\quad 83$

Not studied $\quad 83$

Not studied 83

Not studied $\quad 8$

Not studied $\quad 110$

Not studied $\quad 118$

Not studied 5

Not studied 5

Kills fish,

tadpoles

Not studied

Not studied $\quad 99$

Not studied $\quad 99$

Low fish toxicity $\quad 99$

Not studied 5

Kills cercariae, $\quad 131$

tadpoles, mosquito

larvae
"A = "alcohol"
$\mathrm{B}=$ butanol
$\mathrm{Be}=$ benzene

$C=$ chloroform

$\mathrm{E}=$ ethanol

$\mathrm{EA}=$ ethyl-acetate

\section{Acknowledgement}

The authors are indebted to Mrs. Diana KLoos and Miss Anne JURY for their secretarial assistance and to many colleaques for their help in diverse ways in the preparation of the manuscript; our special thanks are extended to Dr. Freddy R. Medina.

\section{References}

(1) Abdulla, W. A., H. Kadry, S G. Mahran, E. H. El-Raziky and S. El-Nakib: Preliminary studies on the anti-schistosomal effect of Ammi majus, L. Egyptian Journal of Bilharziasis, 4, 19 (1977).

(2) Abou El-Hassan, A. A., H. A Shoeb, A. S. Rafivan, M. A. ElEman and S. M. El-Amin: The molluscicidal properties of Euphorbia lacta, Proceedings of the Tenth International Congress of Tropical Medicine and Malaria, p. 360 (1980).

(3) Abu-Shady, H. and T. O. Soine: The chemistry of Ambrosia maritima, L. I. Journal of the American Pharmaceutical Association, 42, 387 (1953).

(4) Adewunmi, S. O. and V. O.

$$
\begin{aligned}
\mathrm{Er} & =\text { ether } \\
\mathrm{H} & =\text { hexane } \\
\mathrm{M} & =\text { methanol }
\end{aligned}
$$

Marquis: Laboratory and field trails of the molluscicidal property of Calliandra portoricensis (Jacq) benth., Proceedings of the Tenth International Congress of Tropical Medicine and Malaria, p. 354 (1980).

(5) Adewunmi, C. O. and E. A Sofowora: Preliminary screening of some plant extracts for molluscicidal activity, Planta Medica, Journal of Medicinal Plant Research, 39,57 (1980).

(6) Adewunmi, C. O., S. K. Adesina and V. O. Marquis: On the laboratory and field evaluation of the molluscicidal properties of Tetrapleura tetraptera, Proceedings of the Tenth International Congress of Tropical Medicine and Malaria, p. $354(1980)$

(7) Al-Azzawil, H. T. and H. B. Banna: Some enzyme histochemi- cal study on certain mouse tissues after 'Bayluscide' administration, Proceedings of the Tenth International Congress of Tropical Medicine and Malaria, p. 355 (1980).

(8) Alzérreca, A., B. Arboleta and G. Hart: Molluscicidal activity of natural products. The effect of Solanum glycosidic alkaloids on Lymnaea cubensis snails, J. Agric. Univ. Puerto Rico, 57, 69 (1981).

(9) Amin, M. A., A. A. Daffala and O. A. El Moneim: Preliminary report on the molluscicidal properties of habat-el-mollok, Jatropha sp., Trans. Roy. Soc. Med. Hyg., 66,805 (1972).

(10) Amorin, J. P. and S. B. Pessoa: Experiencia de alguns vegetais como moluscocida, Revista Brasileira de Malariologia e Doenças tropicais, 14, 254 (1962).

(11) Anantaraman, M.: Biological 
control of aquatic snails, Indian Journal of veterinary Sciences, 25 , 65 (1955).

(12) Archibald, R. G.: The use of the fruit of the tree Balanites aegyptiaca in the control of schistosomiasis in the Sudan, Trans. Roy. Soc. Trop. Med. Hyg., 27, 207 (1933).

(13) Assefa, G.: Studies of the insecticidal property of endod. In Lemma, A., D. Heyneman, and $\mathrm{H}$. Kloos (Eds.): Studies on the molluscicidal and other properties of the endod plant Phytolacca dodecandra. Unpublished report, San Francisco, pp. 203, 1979.

(14) Ayensu, E. S.: Medicinal Plants of West Africa, Alconac, Mich., 1978, Reference Publications.

(15) Azevedo, J. F and L. Medeiros: L'action molluscicide d'une plante de l'Angola, la Securidaca longipedunculata Fresen. 1837. Bulletin de la Société de Pathologie Exotique, 56, 68 (1963).

(16) Baalawy, S. S.: Laboratory evaluation of the molluscicidal potency of a butanol extract of Phytolacca dodecandra. Bull. Wld. Hith. Org. , 47. 422 (1972).

(17) Barbosa, F. S. O. B. Calado, J. G. D. Moraes and A. D. Almeida: Ação moluscocida sinérgica da saponina do Sapindus saponaria e pentochlorophenato de sodio. Publ. Aulsa Inst. Aggeu. Magalhaes, I, 129 (1952)

(18) Barbosa. F. S. and D. A. Mello: Ação moluscicida de plantas, Revista Brasileira de Pesquisas Medica e Biologia, 2, 364 ( 1969 ).

(19) Blunden, G., J. A . Jaffer, K Jewers and J. Barbour: Rockogenin formation during the processing of Agave sisalana leaves of hegogenin, Lloydia, 40. 218 (1977).

(20) Bollinger, W. H.: Sustaining renewable resources: techniques from applied botany. Unpublished report, Environmental Applications, Plant Resources Institute, Salt Lake City, Utah 1979.

(21) Bollinger, W. H. and Z. S Wochock: New advances in horticulture applicable to development and applied ecology. V. Paper read at the International Symposium on Tropical Ecology, Kuala Lumpur. Malaysia 1979.

(22) Bond, H. W.: Arguments in favour of the use of natural products, particularly plant products. as molluscicides, Unpublished report 1973

(23) Bousfield. J. D.: Plant extracts and chemically triggered positive rheotaxis in Biomphalaria glabrata (Say), snail intermediate host of Schistosoma mansoni (Sambon) Journal of Applied Ecology. 16.681 (1979)

(24) Cheng. T. H.: Schistosomiasis in mainland China: a review of research and control programs since 1949. Amer. J. trop. Med. Hyg. $20.26(1971)$

(25) Cordell, G. A. and N. R Farnsworth: Experimental anti- tumor agants from plants, 197476, Lloydia, 40, 1 (1977)

(26) Cowper, S. G.: The effect of certain inorganic and vegetable substances on the English pond snail Planorbis corneus (Linne, 1958), Ann. trop. Med. Parasitol., 42, 119 (1948).

(27) Cushing, E. C.: Schistosomiasis: further studies on the development of a prophylactic drug in vivo tests with a promising fraction of an extract of Yucca palida leaves, Military Medicine, 125, 747 (1960).

(28) Daffalla, A. A. and M. A. A min: Laboratory and field evaluation of the molluscicidal properties of habat-el-mollok (Croton spp.). E. Afr. J. Med. Res., 3, 185 (1979). (29) Dalziel, J. M.: The Useful Plants of West Tropical Africa, London 1936. Crown Agents. (30) Dossaji, S. F., M. G. Kairu. A. T. Gondwe and J. H. Ouma: On $t^{2}$ evaluation of the molluscicidal properties of Polygonum senegalense forma senegalense, Lloydia, 40.290 ( 1977)

(31) Duncan, J. and A. Lemma: A first annual report on the bilharzia control project at HVA WonjiShoa with some remarks concerning HVA Metahara. Unpublished report. Institute of Pathobiology. Addis Ababa 1970.

(32) El-Kheir. Y. M. and M. S. ElTohami: Investigation of molluscicidal activity of certain Sudanese plants used in folk-medicine. I. and II. J. trop. Med. Hyg., 82, 237 (1979).

(33) El-Sawy, M. F. E.: The effect of damsissa plant in the control of Schistosoma and liver fluke (in Arabic). Unpublished report, The High Institute of Public Health, Alexandria University. Alexandria. Egypt 1979

(34) El-Sawy, M. F. . K. Bassiouny and A. I. El-Magdoub: Biological control of schistosomiasis. Ambrosia maritima (damsissa) for snail control, Journal of the Egyptian Society of Parasitology, 11, 99 (1981).

(35) Farnsworth. N. R.: Biological and phytochemical screening of plants, Journal of Pharmaceutical Sciences, 55, 225 (1966).

(36) Farnsworth, N. R. and G. A Cordell: A review of some biologically active compounds isolated from plants as reported in the 1974-1975 literature. Lloydia, 39. 420 (1976)

(37) Farnsworth, N. R., W. D Loub. M. L. Quinn, G. A. Cordell and D. D. Soejarto: A computerized natural products information system. Journal of natural Products, 42, 689 (1979)

(38) Felker. P. and R. S. Bandurski: Uses and potential uses of leguminous trees for minimal energy input agriculture. Econ. Bot...33. 172 (1979).

(39) Frischkorn. C. G.: Cercaricidal activity of some essential oils of plants from Brazil. Naturwissenschaften, 65,480 (1978).
(40) Fuegner, A.: Inhibition of inflammations of immunologic origin by the plant steroid withaferin $\mathrm{A}$., Arzneimittel-Forschung, 23, 932 (1973).

(41) Getaneh, M. and A. Lemma: Progress Report I. Comparative studies of three molluscicides (Bayluscide, Frescon and endod) to microflora (Phytoplankton) and microfauna (zooplankton, Crustacea sp. and Arthropoda insects), II. Toxicity of endod to fish and snails. In Lemma, A., D. Heyneman and H. Kloos (Eds.): The molluscicidal and other uses of the endod plant Phytolacca dodecandra, Unpublished Report, San Francisco, pp. $209-212,1979$

(42) Gevrey, J., S. Michel and J. Euzeby: Mise en évidence de la toxicité d'un complexe algal sur la faune aquatique, Vet. Med. Comp. Lyon, 74, 191 (1976)

(43) Graham, K.. E. A. Graham and G. H. N. Towers: Cercaricidal activity of phenylheptatriyne and atertienyl, naturally occurring compounds in species of Asteraceae and Compositae, Canad. J. Zool.. $58,1955(1980)$

(44) Haerdi, F.: Die Eingeborenen-Heilpflanzen des Ulanga-Distriktes Tanganjikes (Ostafrika). Acta Tropica. Supplementum, 8, 1 (1964).

(45) Hostettmann, K., M. Hostettman-Kaldas and $K$. Nakanishi: Molluscicidal saponins from Cornus florida L. Helvetica Chimica Acta, 6I, 1990 (1978).

(46) Hostettman. K.: Saponins with molluscicidal activity from $\mathrm{He}$ dera helix L. Helvetia Chimica Acta, 63, 606 (1980).

(47) Jardin, C.: List of Food Plants used in Africa (2nd ed.). Nutrition Information Documents Series No. 2, Food and Agriculture Organization, Rome 1970

(48) Johns, T., K. Graham and G. H. N. Towers: Molluscicidal activity of isobutylamides in Heliopsis longipes (Asteraceae) and Wedelia parviceps (Compositae). Phytochem.

(49) Kloos, H.: Preliminary studies of medicinal plants and plant products in markets in central Ethiopia. Ethnomedicine, 4, 63 (1976).

(50) Kloos. H. and A. Lemma: Schistosomiasis in irrigation schemes in the Awash Valley, Ethiopia. Am. J. trop. Med. Hyg., 26, 899 (1977).

(51) Kloos, H., W. Sidrak, A. A. M. Michael. E. W. Mohareb and G. 1. Higashi: Disease concepts and treatment practices relating to schistosomiasis haematobium in Upper Egypt. J. trop. Med. Hyg. in press. (52) Krochmal. A and P. W. Leguesne: Phytolacca americana: possible source of a molluscicide. U.S.D.A. Forest Service Research Paper NE-177. 177. I (1970).

(53) Lemma. A.: A preliminary report on the molluscicidal property of endod (Phytolacca dodecandra)

Ethiopian Medical Journal, 3, 187 (1965).

(54) Lemma, A.: Laboratory and field evaluation of the molluscicidal property of Phytolacca dodecandra, Bull. Wld. HIth. Org. . 42, 597 (1970).

(55) Lemma, A. and B. N. Ames: Screening for mutagenic activity of some molluscicides. Trans. Roy. Soc. Trop. Med. Hyg., 69, 167 (1975).

(56) Lemma, A and P. Yau: Studies on the molluscicidal properties of endod (Phytolacca dodecandra).

II. Ethiopian Medical Journal, 12 . 109 (1974).

(57) Lemma, A. and P. Yau: Studies on the molluscicidal properties of endod (Phytolacca dodecandra), III. Ethiopian Medical Journal, 13 . 115 (1974).

(58) Lemma, A. G. Brody, G. W Newell, R. M. Parkhurst and W. A. Skinner: Endod (Phytolacca dodecandra), a natural product molluscicide, increased potency with butanol extraction. Journal of Parasitology, 58, 104 (1972)

(59) Lemma, A.. D. Heyneman and H. Kloos (Eds.): Studies on the molluscicidal and other properties of the endod plant Phytolacca dodecandra. Unpublished report, San Francisco 1979

(60) Lemma, A.. A. Maxwell and G. Brody: Antimicrobal and antihelminthic activites of endod (Phytolacca dodecandra). In Lemma. A., D. Heyneman and H. Kloos (Eds.): Studies on the molluscicidal and other properties of the endod plant Phytolacca dodecandra. Unpublished report, San Francisco. 153 (1979).

(61) Lemma, A.. M. B. Flemings. G. Assefa and T. M. Tesfa Yohannes: Studies on the larvicidal properties of endod (Phytolacca dodecandra). In Lemma, A., D. Heyne- 
plant Phytolacca dodecandra. Unpublished report, San Francisco, pp. 216-219, 1979

(65) Lemma, T. and A. Lemma: Colorimetric determination of endod. In Lemma, A., D. Heyneman and $\boldsymbol{H}$. Kloos (Eds.): Studies on the molluscicidal and other properties of the endod plant Phytolacca dodecandra. Unpublished report, San Francisco, pp. 230-240, 1979.

(66) Lemma, T. and L. W. Yohannes: Selected stage for endod berry harvesting. In Lemma, A., D. Heyneman and H. Kloos (Eds.): Studies on the molluscicidal and other properties of the endod plant Phytolacca dodecandra. Unpublished report, San Francisco, pp. $241-$ $246,1979$.

(67) Lloyd, H. A., C. Denny and G. Krishna: A simple liquid chromatographic method for analyss and isolation of the unsaturated components of anacardic acid. Unpublished report, National Heart, Lung and Blood Institute, National Institutes of Health, Bethesda, Maryland, 1980.

(68) Lugt, C. B.: Personal communication.

(69) Lugt, C. B.: Chemical and quantitative aspects of Phytolacca dodecandra berries as a molluscicide. Ethiopian Medical Journal, 16, 140 (1978).

(70) Lugt, C. B.: Phytolacca dodecandra (endod) fas a means to control schistosomiasis transmitting snails. In Lemma H., D. Heyneman and $\mathrm{H}$. Kloos (Eds.): Studies on the molluscicidal and other properties of the endod plant Phytolacca dodecandra, 1979.

(71) Lugt, C. B.: Development of molluscicidal potency in short and long staminate racemes of Phytolacca dodecandra. Planta Medica, $38,68(1980)$.

(72) Lugt, C. B.: Phytolacca dodecandra Berries as a Means of Controlling Bilharzia Transmitting Snails. Addis Ababa 1981, Litho Printer.

(73) Luttermoser, G. W.: La campaña antibilharziana en Venezuela. Paper read at the Twelfth Conference San Panamericana, Caracas 1946.

(74) Maegraith, B : Schistosomiasis in China, Lancet $l$ (7013), 208 (1958).

(75) Mahran, G. H., M. Saleh, G W. El-Hossary, H. M. Motawte and A. M. Mohamed: A contribution to the molluscicidal activity of Canna indica L. family Cannaceae as a method for control of Schistosoma, Egyptian J. of Bilharziasis, 1,279 (1974)

(76) Malinow, T.: Personal com munication

(77) Mamo, E.: A short note on toxicity studies of endod (Phytolacca dodecandra) on sheep and dogs. In Lemma, A., D. Heyneman and $H$. Kloos (Eds.): Studies on the molluscicidal and other properties of the endod plant Phytolacca dodecan- dra. Unpublished report, San Francisco, p. $246,1979$.

(78) Maradufu, A. and J. H. Ouma: A new chalcone as a natural molluscicide from Polygonum senegalense, Phytochemistry, 17, 823 (1977).

(79) McCullough, F. S.: The distribution of Schistosoma mansoni and Schistosoma haematobium in $\bar{E}_{\text {ast }}$ Africa, Tropical and Geographical Medicine, 24, 199 (1972).

(80) McCullough, F. S., P. Gayral. J. Duncan and J. Christie: Molluscicides in schistosomiasis control, Bull. Wld. Hlth Org 58, 681 (1980). (81) Medina, F. R.: Personal communication.

(82) Medina, F. R. and R. Woodbury: Terrestrial plants molluscicidal to lynmaeid hosts of Fasciola hepatica in Puerto Rico. Journal of Agriculture of the University of Puerto Rico, 63, 366 (1979).

(83) Medina, F. R. and L. S. Ritchie: Molluscicidal activity of the Puerto Rican weed, Solanum nodiflorum Jacquin, against snail hosts of Fasciola hepatica, Econ. Bot. 34,368 (1980).

(84) Michael, T. G. and L. W. Yohannes: Preliminary report of the investigation on insect pests. In Lemma, A., D. Heyneman and $\mathrm{H}$. Kloos (Eds.): Studies on the molluscicidal and other uses of the endod plant Phytolacca dodecandra. Unpublished report, San Francisco,pp. 247-251, 1979

(85) Morais, J. G., A. M. Almeida, F. S. Barbosa and O. B. Calado Açáo moluscocida sinérgica da saponina de Sapindus saponaria pentachlorofenato de sódio, Ann. 10th Congr. Bras. Hig. Belo Horizonte, pp. $370-373$ (1953).

(86) Mozley, A.: Fresh-water mollusca of the Tanganyika Territory and the Zanzibar Protectorate, and their relation to human schistosomiasis. Transactions of the Royal Society of Edinburgh, 59, 687 (1939)

(87) Mozley, A.: Molluscicides, London 1952, Lewis.

(88) Msangi, A. S. and C. Zeller: Investigations on the molluscicidal effects of Sapindus saponaria on the bilharzia vector snail, Bulinus (Physopsis) africanus. Proceedings of the East African Academy, 3, 52 (1965).

(89) Muley, E. V.: Biological and chemical control of the vector snail Melania scabra (Gastropoda: Prosobranchia), Bulletin of the Zoological Survey of India, $1,(1978)$.

(90) Nakanishi, K. and I. Kubo: Studies on warburganal, murzigadial and related compounds, Israel J. Chem. 16, 28 (1977)

(91) Otieno, L. H.: Observations on the action of sisal waste on freshwater pulmonate snails, East African Agricultural and Forestry Journal, 32, 68 (1966).

(92) Parkhurst, R. M.: Endodwonder weed of Africa. In Lemma, A. D. Heyneman and $\mathbf{H}$. Kloos (Eds.): Studies on the molluscicida and other uses of the endod plant Phytolacca dodecandra. Unpublished report, San Francisco, pp. 252-255, 1979

(93) Parkhurst, R. M.: The chemotaxonomy of Phytolacca species, Indian Journal of Chemistry, 13, 757 (1975).

(94) Parkhurst, R. M., D. W. Thomas, W. A. Skinner and L. W. Cary: Molluscicidal saponins of Phytolacca dodecandra: Lemmatoxin, Canadian Journal of Chemistry, 52 , 702 (1974)

(95) Pereira, J. P. and C. P. Souza: Ensaios preliminares com "Anacardium occidentale" como molluscicida, Ciéncia e Cultura, 26, 1054 (1974).

(96) Pereira, J. P. and C. P. Souza: Influencia de harmonios de vertebratos sobre reproducao de B. glabrata e na infeccao pelo $S$. mansoni, Rev. Bras. Pesq. Méd. e Biol., 11, 135 (1978).

(97) Pereira, J. P., C. P. Souza and M. M. Mendes: Molluscicidal properties of the Euphorbia cotonifolia L., Rev. Bras. de Pesuisas Méd. e Biol., 11, 345 (1978)

(98) Pinto, C. and A. F. Almeida: Um nóvo métouo de profilaxia da esquistosome mansoni. Mem. Inst. Osw. Cruz, 40, 291 (1944).

(99) Plank, H. K.: All parts of the desert date toxic to snails, Annual Report of the US Department of Agriculture, AES Puerto Rico, Mayaquez, Puerto Rico, 24, (1945)

(100) Polunin, N.: Introduction to Plant Geography and some Related Sciences, London 1967, Longmans. (101) Purchio, A and R. Campos: Molluscicidal activity of aflotoxin, Rev. Inst. Med. Trop. Sao Pauli, $12,236(1970)$

(102) Rao, V. P., V. D. Chowdary and R. Narayanan: Effect of aqueous tobacco extract on the bioenergetic parameters of the host snail Lymnaea luteola, Proceedings of the Tenth International Congress of Tropical Medicine and $\mathrm{Ma}-$ laria, p. 355 (1980).

(103) Renno, R.: Contribuiçăo ao estudo das Characeae para o combate à esquistosome, Anales de là Real Academia de Farmacia, 38, 688 (1972).

(104) Ritchie, L. S., G. V. Hillyer and E. C. Cushing: Molluscicidal and cercaricidal activities of substances contained in tissues of certain plants, Military Medicine, 8 , 795 (1963).

(105) Rouquayrol, M. A.: Personal communication.

(106) Rouquayrol, M. A., M. Pinheiro de Souza and F. J. Abreu Matos: Actividad molusquicida del Pithecellobium multiflorum, Boletin de la Oficina Sanitaria Panamerica na, 170 (1973)

(107) Rouquayrol, M. A., M. Pinheiro de Souza and F. Abreu Matos: Actividade moluscicida de $\mathrm{Pi}$ thecellobium multiflorum, Revista da Sociedade Brasileira de Medicina Tropical, 7, 11 (1973).

(108) Rouquayrol, M. Z., M. C. Fonteles, J. E. Alencar, F. J. Abreu Matos and A. A. Craveiro: Actividade moluscicida de essenciales oleos de plantas do Nordeste Brasileiro, Rev. Bras. Pesqui. Med. Biol., 13, 135 (1980).

(109) Ruys, C. D.: Bilharziasi, n Kilombero Estate. Unpublished report, Arusha Planting Company, A rusha Chini, Tanzania 1965.

(110) Saliternik, Z. and G. Witenberg: Investigations on the control of bilharziasis vectors in Israel, Bull. Wld. Hith. Org., 21, 161 (1959).

(11) Sandberg, F.: Biological and chemical screening of plant materials. In Bendz, G. and J. Santesson (Eds.): Chemistry in Botanical Classification. Proceedings of the 25th Nobel Symposium, 1973, 303, New York 1974, Academic Press. (112) Schultes, R. E.: The future of plants as biodynamic compounds. In Swain, T. (Ed.): Plants in the Development of Modern Medicine, 103, Cambridge 1974, $\mathrm{Har}$ vard Univ. Press.

(113) Sherif, A.-F. and M. F. E. D. El-Sawy: Molluscicidal action of Egyptian herbs 1. Alexandria Med. ical Journal, 8, 139 (1962).

(114) Sherif, A.-F. and M. F. E. D. El-Sawy: Laboratory trials of the molluscicidal action of Egyptin herbs, Proceedings of the First Symposium on Bilharziasis, pp. 690 -694 . Cairo, National Information and Documentation Centre (1962). (115) Sherif, A.-F. and M. F. E. D. El-Sawy: Field trials of the molluscicidal action of Ambrosia maritima (damsissa), Bulletin of the High Institute of Public Health of Alexandria, 7, 1 (1977).

(116) Shoeb, H. A. and M. A. ElEman: The molluscicidal properties of substances gained from Ambrosia maritima, Proceedings of the International Conference on Schi- 
cashew nut shell liquid. Planta Medica, 44, 175 (1982)

(123) Täckholm, V.: Student Flora of Egypt, Cairo 1974, Cairo University Press.

(124) Tampion, J.: Dangerous Plants, New York 1977, Universe Books.

(125) Teckie, Y. and L. W. Yohannes: The endod research project. Progress report and plan of work. In Lemma, A., D. Heyneman and H. Kloos (Eds.): Studies on the molluscicidal and other properties of the endod plant Phytolacca dodecandra. Unpublished report, San Francico, pp. 256-262, 1979.

(126) Teesdale, C.: Freshwater molluses in the Coast Province of Kenya with notes on an indigenous plant and possible use in the control of bilharzia, East African Medical Journal, 31, 351 (1965).

(127) Tekle, A.: Molluscicidal property of Sesbania sesban, Ethiopian Medical Journal, 15, 131 (1977).

(128) Telek, L., H. Delphin and E. Cabanillas: Solanum mammosum as a source of solasodine in the lowland tropics, Economic Botany, 31, 120 (1977).

(129) Torrealba, J. F., J. V. Scorza, M. S. Sanabria, A. D. Vasquez, B. I. Ramos, B. Riccardi and L. S. Jordan: Nota preliminar sobre la accion malaquisita del fruto de paraparo (Sapindus saponaria) Gaceta Medica, 61299 (1953).
(130) Uphof, J. C. T.: Dictionary of Economic Plants, Lehre 1968, J. Cramer.

(131) Wagner, V. A.: The possibility of erradicating bilharzia by extensive planting of the tree Balanites, South African Medical Journal, $10,10(1933)$

(132) Warren, K. S. and P. A. Peters: Cercariae of Schistosoma mansoni and plants, attempt to penetrate Phaseolus vulgaris and $\mathrm{He}$ dychium coronarium, Nature, 217 , 647 (1968).

(133) Watt, J. M. and M. G. Breyer-Brandwijk: The Medicinal and Poisonous Plants of Southern and Eastern Africa, Edinburgh 1962 , E. and S. Livingstone.

(134) WHO: Molluscicides, Second Report of the Expert Committee on Bilharziasis, WHO Technical Report Series No. 214 (1961)

(135) WHO: Molluscicide screening and evaluation. Bull. Wld. Hlth. Org., 33, 567 (1965).

(136) WHO: The Promotion and Development of Traditional Medicine, Report of a WHO Meeting, WHO Technical Report Series, No. 622 (1978).

(137) WHO: Epidemiology and Control of Schistosomiasis, WHO Technical Report Series, No. 643 (1980).

(138) Wossen, C. G. and A. Lemma: Antimicrobial properties of endod. In Lemma, A., D. Heyneman and $\mathbf{H}$. Kloos (Eds.): Studies on the molluscicidal and other properties of the endod plant Phytolacca dodecandra. Unpublished report, San Francisco, pp. 258-259, 1979.

(139) Yasuraoka, K.: Laboratory evaluation of the molluscicidal properties of triterpenoid saponin, a molluscicidal fraction from endod (Phytolacca dodecandra), against Oncomelania nosophora). Unpublished WHO document, WHO/ SCHISTO/71.8 (1971).

(140) Yasuraoka, K, Y. Irie, H. Takamura, J. Hashiguchi, M. J. Santos and A. T. Santos: Laboratory and field assessment of the molluscicidal activity of gogo (Entada phaseoloides) against the amphibious snail intermediate host of Schistosoma japonicum, Japanese Journal of Experimental Medicine, 47, 483 (1977).

(141) Yasuraoka, K., J. Hashiguchi and E. A. Banez: Laboratory assessment of the molluscicidal ac- tivity of the plant Croton tiglium against Oncomelania snails. Proceedings of the Philippine-Japan Joint Conference on Schistosomiasis Research and Control, Manila, the Japan International Cooperation Agency, pp. 106-108 (1980).

(142) Yasuraoka, K., J. Hashiguchi and B. L. Blas: Laboratory assessment of the molluscicidal activity of the plant Jatropha curcas against Oncomelania snails, Proceedings of the Philippine-Japan Joint Conference on Schistosomiasis Research and Control, Manila, The Japan International Cooperation Agency, pp. 110-112 (1980).

(143) Yohannes, L. W.: Studies on the phytotoxicity of endod (Phytolacca dodecandra), Proceedings of the O. A. U. Symposium on Schistosomiasis, Addis Ababa, Niamey, Niger, O. A. U./S. T. R. C. Publications Bureau (1970).

\section{Address: Dr. Helmut Kloos, 2307 N. Backer, \\ Fresno, California 93703}

(USA)

Dr. Fergus McCullough, Ecology and Control of Vectors, Division of Vector Biology and Control,

World Health Organization Avenue Appia

1211 Geneva 27 (Switzerland) 